\title{
CONTROLLING OF THE BLACK PARLATORIA SCALE INSECT PARLATORIA ZIZIPHUS(LOCUS) (HOMOPTERA: DIASPIDIDAE) INFESTED CITRUS TREES USING LOCAL SAFE MATERIALS
}

\author{
E L-SISI, A. G. ${ }^{1}$, MAHA I. ABD EL- RAZZIK ${ }^{2}$ AND \\ EVOON A. OSMAN ${ }^{2}$
}

1. Central Agricultural Pesticides Laboratory, ARC, Dokki, Giza

2. Plant Protection Research Institut, ARC, Dokki, Giza

(Manuscript received 19 October 2008)

\begin{abstract}
Three different materials of different groups, the first: surfactants (Sisi-6), the second : acidic materials (sulphonic acid) and the third: sticking agent (glue), of those proved pesticidal efficiency against other insects, were tested for controlling scale insects infested citrus trees. The following physico-chemical properties for the tested materials were determined : solubility in water, free acidity or alkalinity and surface tension of their solutions in water at concentrations $0.5,1.0$ and $1.5 \%$, also their pesticidal efficiency against scale insects were determined by spraying each concentration on three branches of orange tree highly infested with the black parlatoria scale insect. Parlatoria ziziphus (Locus). Infestation was determined before spraying and after 30 days of spraying then reduction percentage were calculateted.

Obtained results indicated that all tested materials showed suitable solubility in water also indicated that sulphonic acid showed higly acidity while glue is high in alkalinity and all tested materials reduced surface tension of water, sulphonic followed by Sisi-6 showed the higher effect followed by glue. The above physico-chemical properties indicated that the tested material could be use as spraying by dissolving them in water, also give a predication that they will give high scalicide effect. Results of semifield experiment indicated that all tested materials showed high scalicide effect as indicated by $\%$ mean reduction of inspected individual (pre-adult, adult female and graved female)and it could be said that Sisi -6 at $0.5,1.0,1.5 \%$ and sulphonic at $1.5 \%$ and $1.5 \%$ glue gave successful control of this pest without showing any phytotoxic effect.
\end{abstract}

\section{INRODUCTION}

Scale insects are among the pests that cause injury to citrus and other horticulture crops. It is undesirable of using harzad conventional pesticides for controlling pests that infested citrus crops since it is considered among food crops therefore mineral oils were considered as a best alternative used instead of those hazard conventional pesticides and recommend for controlling scale insects in Egypt, since beginning of 1960 up to now (Anonymous 2003). Unfortunately petroleum oil world prise increased in a few years later as a result of increasing of using it as a 
source of energy and also of using petroleum oil in petrochemical industries, therefore, efforts should be directed toward another new local alternative for controlling scale insects.

Between local alternative groups proved insecticidal and acaricidal effects : surfactants which proved the pesticidal efficiency against aphids (El- Hariry and El-Sisi 1991)also proved the pesticidal efficiency against other sucking pierce pests: white fly and spider mite, (Rizk., et al 1999 and Mousa and El-Sisi 2001). Also, the acidic material proved their ability for controlling Nosema apis disease infested honeybee colonies, (Abo- Lila et al., 1999) also for controlling sucking pierce pests infested squash crop (Mousa and El- Sisi, 2001). Sticking agent glue proved pesticidal efficiency against sucking pierce pests infested cotton plants, (Rizk et al., 1999).

The aim of this research is determination the scalicide effect of the above alternative groups proved insecticidal and acaricidal effects : surfactant : (Sisi-6), acidifying material (sulphonic acid) and sticking agent (glue) against scale insect the black parlatoria Parlatoria ziziphus infested citrus trees.

\section{MATERIALS AND METHODS}

Surfactant (Sisi-6) : It is prepared by neutralization of dodecyl benzene sulphonic acid with potassium alkaline.

Sulphonic acid : It is produced by El- Ameria Co for petroleum refining, Alex.

Sticking agent : glue: it is an animal product (albo-protein) supplied by El-Gomhoria Co. for chemicals, Egypt.

\section{Determination of physico-chemical properties of the tested materials}

Solubility in water is determined by the method mentioned by (El-Sisi, 1981) free acidity or alkalinity was determined according to CIPAC MT.31 (2001). Surface tension for the diluted material in water for spray solution at $0.5,1.0$ and $1.5 \%$ was determined using by DuNouy Tensiometer.semi-field evaluation of the tested materials against the scale insect P.zizphus.

Experiment was conducted according to Ministry of Agriculture protocol (1993) but at small scale on orange trees cultivated at Plant Protection Research Institute at highly infested with the black parlatoria scale insect $P$. ziziphus. Spraying was done on 2008 using hand sprayer provided with one nozzle, using three concentrations of each tested materials : $0.5,1.0$ and $1.5 \%$. Each concentration was sprayed on three branches only on tree, one tree was left without spraying as a control. Pesticidal efficiency was determined by collecting 10 leaves from each treatment before spraying and after 30 days of spraying and inspecting them by the aid of stereo microscope, 
then the mean number of alive insect/leaf was recorded and reduction percentages also were calculated according to Henderson and Tilton equation, (1955).

Phytotoxic effect : It was determined by recording any flaming curl and colour change occurred in leaves of treated plants up to 30 days after spraying.

\section{RESULTS AND DISCUSSION}

Results shown in table (1) indicated that all the tested materials soluble in water in different rates sulphonic showed the highest solubility followed by glue and Sisi-6 therefore it could use for spraying trees by dissolving them in water. Also, the same table indicated that sulphonic acid showed the highest acidity while glue showed the highest alkalinity and this give a prediction of both two materials will show pesticidal efficiency as a result of its hazard effect on pest cuticle also for making the target media unsuitable for pest surviving (Abou-Lila et al., 1999and Mousa and El-Sisi 2001). Surface tension of water decreased from 72 dyne/cm to 26.31-27.36 for Sisi-6 diluted solution and to $24.87-26.31$ for sulphonic acid and give a prediction of the tab materials will give high insecticidal effect as mentioned by El- Hariry and El-Sisi, (1999) who stated that the pesticidal efficiency of any surfactant is increased by its ability in decreasing the surface tension of water.

\section{Scalicide effect of the tested materials against the black parlatoria scale insect Parlatoria ziziphus}

Results in table (2) and Fig. (1) indicated that all tested materials had scalicide effect against P.zizyphus infested citrus trees (orange) and the effect increased as concentration of the tested material increased. According to the Ministry of Agriculture recommendations for using the natural products and safe material in controlling pests, effective material should give $80 \%$ reduction after one month. According to this recommendation, it could be said that Sisi-6 by all tested concentration, sulphonic acid at $1.5 \%$ and glue at $1.5 \%$ are succeeded for controlling this pest without showing any phytotoxi effect. Generally, it could be explained the mode of action of the tested materials as the following :

1-Surfactant, Sisi-6, the pesticidal efficiency increased by its ability in decreasing the surface tension of water ( as mentioned in table 1), the effect might due to solving the epicuticle of pests body as a result of its emulsify, then cause mortality.

2- Sulphonic acid: the effect is due to its ability in decreasing surface tension of water as mentioned before for Sisi-6, also to its high acidity that cause impairment of cuticle layer of the pest also making the target media unsuitable for pest surviving , ( AbouLila et al., 1999 and Mousa and El-Sisi, 2001). 
3- Glue having two action as surfactant and by reacting with its alkaline properties with cuticle layer of the pest also making the target media unsuitable for pest surviving, ( Abou-Lila et al., 1999).

Table 1. Physico-chemical properties of the tested materials

\begin{tabular}{|c|c|c|c|c|c|c|}
\hline \multirow{2}{*}{$\begin{array}{l}\text { Tested } \\
\text { material }\end{array}$} & \multirow{2}{*}{$\begin{array}{c}\text { Solubility in } \\
\text { water \% } \\
\&(\text { Wt./V) }\end{array}$} & \multirow{2}{*}{$\begin{array}{l}\text { Free acidity } \\
\% \text { as } \mathrm{H}_{2} \mathrm{SO}_{4}\end{array}$} & \multirow{2}{*}{$\begin{array}{l}\text { Free alkalinity } \\
\% \text { as } \mathrm{NaOH}\end{array}$} & \multicolumn{3}{|c|}{$\begin{array}{l}\text { Surface tension for Conc. } \\
(\%)\end{array}$} \\
\hline & & & & 0.5 & 1.0 & 1.5 \\
\hline Sisi-6 & 10.00 & 0.00 & 0.012 & 27.36 & 26.31 & 26.31 \\
\hline $\begin{array}{l}\text { Sulphonic } \\
\text { acid }\end{array}$ & Miscible & 22.93 & 0.00 & 26.31 & 25.33 & 24.87 \\
\hline Glue & 33.30 & 0.00 & 3.84 & 50.67 & 45.6 & 42.7 \\
\hline Water & & 0.00 & 0.00 & \multicolumn{3}{|c|}{72.0} \\
\hline
\end{tabular}

Table 2. Insecticidal effect of the tested materials against the black parlatoria scale insect, Parlatoria ziziphus

\begin{tabular}{|c|c|c|c|c|c|}
\hline \multirow{3}{*}{ Tested material } & \multirow{2}{*}{ Conc. (\%) } & \multicolumn{4}{|c|}{ \% Reduction after one month of treatment on } \\
\cline { 3 - 6 } & 0.5 & 89.15 & 75.58 & 83.71 & 82.93 \\
\hline \multirow{3}{*}{ Sisi-6 } & 1.0 & 94.46 & 80.0 & 86.06 & 86.84 \\
\cline { 2 - 6 } & 1.5 & 95.39 & 87.15 & 95.39 & 92.43 \\
\hline \multirow{3}{*}{ Sulphonic acid } & 0.5 & 85.07 & 45.60 & 67.0 & 65.89 \\
\cline { 2 - 6 } & 1.0 & 89.39 & 55.32 & 82.14 & 75.62 \\
\cline { 2 - 6 } & 1.5 & 90.00 & 79.55 & 90.45 & 86.67 \\
\hline \multirow{3}{*}{ Glue } & 0.5 & 64.81 & 75.34 & 82.60 & 74.25 \\
\cline { 2 - 6 } & 1.0 & 67.00 & 78.00 & 86.10 & 77.03 \\
\cline { 2 - 6 } & 1.5 & 71.91 & 81.00 & 90.00 & 80.97 \\
\hline
\end{tabular}

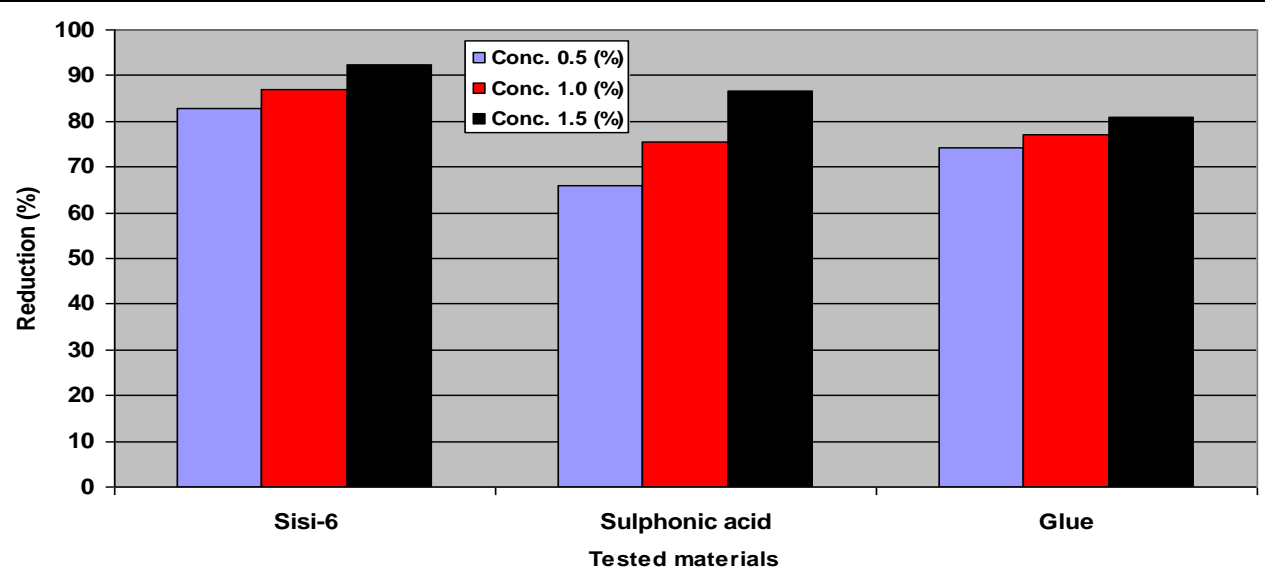

Fig. 1. Insecticidal effect of the tested materials against the black Parlatoria scale insect, Parlaloria zizpihus 


\section{REFERENCES}

1. Abou-Lila, S. M., H. T. Abo El-Enian and A. G. El-Sisi. 1999. Evaluating the efficiency of some organic products and natural products for controlling Nosema apis Zandear disease infesting honeybee colonies. J. Product \& Dev. Zagazig Univ., 4 (2): 33-45.

2. Anonymous. 2003. Agricultural Pests Controlling Programme. Ministry of Agriculture, Egypt. Cin Arabic).

3. CIPAC. 2001. Collaborative International Pesticide Analytical Council. MT.31.

4. El-Hariry, M. A. and A. G. El- Sisi. 1991. Correlation between physico-chemical properties of some local surfactant and their insecticidal activity against the faba bean aphid, Aphis cracivora (Koch). Egypt. J. Agric. Res., 69(1): 289-295.

5. El- Sisi, A. G. 1981. Compatibility of some pesticides and growth regulators. MSc. Thesis, Faculty of Agriculture, Ain-Shams Univ.

6. Henderson, C. F. and E. W. Tilton. 1955. Test with acaricide against the brown wheat mite. J. Econ. Entomol. 48: 157-161.

7. Ministry of Agriculture. 1993. Protocol of Evaluation of the Efficiency of Pesticides in Egyptian culture. pp. 85 (In Arabic).

8. Mousa, G. M. and A.G. El-Sisi. 2001. Testing of some local alternatives : Mineral oils plant materials and surfactant against piercing and sucking pests infesting squash crop. Safe alternative Univ, Egypt 28 (4): 83-90.

9. Rizk M. A., A. G. El-Sisi, N. A. Badr and S. M. Abdel- Halim. 1999. Controlling of cotton sucking pests using safe materials. 2nd Int. Conf. of Pest Control, Mansoura P. 211-221. 


\section{مكافحة الحشرات القشرية بارلاتوريا زيزيفس التي تصيب الموالح باستخدام بدائل أمنة محلية

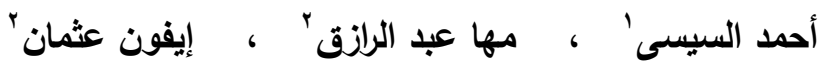

$$
\text { r ا ـ المعدل المركنى للمبيلات - معكز البحوث النزاعية- الدقى - الجيزة. }
$$

تم إختبار ثلاثة مواد من مجموعات مختلفة : 1- المواد ذات النشاط السطحي (سيسي؟) rمـواد حامضية و ذات نشـاط سطحي (حمض السـلفونيك) ب- مـواد لاصـقة (الغـراء) وذللك لمكافحسة الحشرات القشرية علي أثجار الموالح حيث تم دراسة الخواص الطبيعية والكيميائية لهذه المواد: الذوبان في الماء ، الحموضة أو القلوية، التونر السطحي لمحاليلها في الماء كذلك تم إختبار فعالية هذه المواد

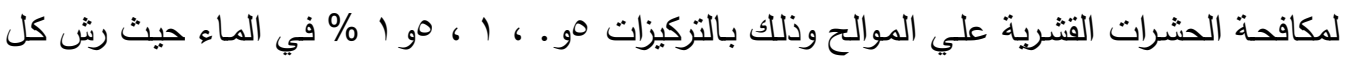

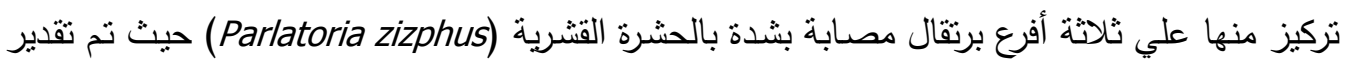

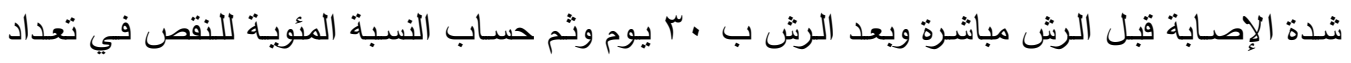
الأفراد الكاملة.

ودلت النتائج المتحصل عليها علي أن كل المواد المختبرة تذوب في المـاء مباشرة كما دلت أن حمض السلفونيك شديد الحموضة وأن الغراء ذات قلوية عالية وأن محاليل هذه المواد في الماء تحت تركيزات هو . ، 1 ، هو 1 \% قللت من التوتز السطحي للماء وأن حمض السلفونيك كان أكثرحموضـة

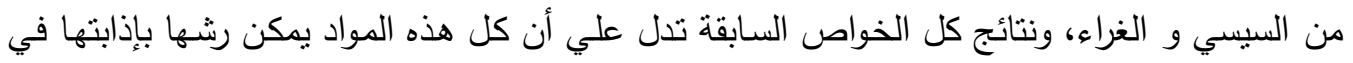

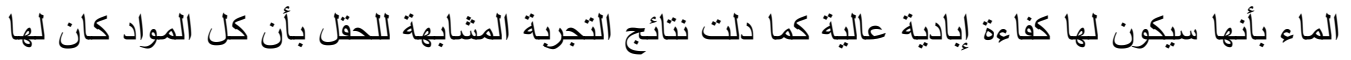
القدرة علي خفض متوسط الأفراد تحت الإختبار ( ما قبل الطور الكامل ، الأفراد الكاملة ، أفراد كاملة

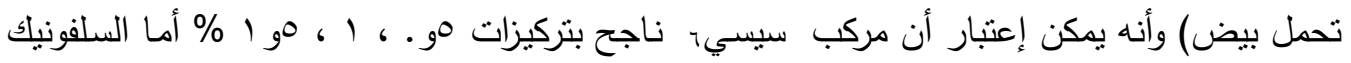

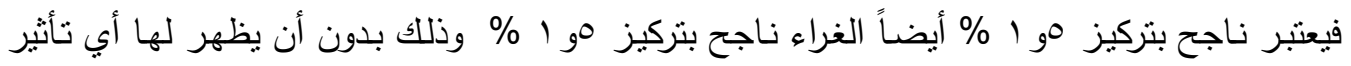

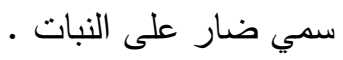

